\title{
Relações Econômicas Brasil-África: A Câmara de Comércio Afro-Brasileira e a Intermediação de Negócios no Mercado Africano ${ }^{1}$
}

Ivo de Santana

\section{Resumo}

Este artigo traz algumas reflexões acerca da presença empresarial brasileira no mercado africano, enfocando particularmente a experiência africana da Câmara de Comércio Afro-Brasileira. Objetiva responder a três questôes principais: sob que motivações o comércio Brasil-África obteve um notável crescimento entre os anos 70 e 90? Quais as perspectivas que se apresentam para o empresário brasileiro que deseje iniciar negócios na África? Qual o estado atual de iniciativas que emergiram naqueles anos? Mediante pesquisa bibliográfica e entrevistas com executivos que atuaram na África, além de especialistas em comércio exterior, constatou que, nos anos mencionados, o governo brasileiro concedia generosos incentivos aos empreendimentos que se voltassem para o mercado africano, estimulando a criação de muitas empresas e o direcionamento de muitas operações para aquele Continente. Com o fim dessa política privilegiada, muitas empresas fracassaram, enquanto outras permanecem em atividade, a exemplo da Câmara, que evidencia dificuldades de prospectar novas oportunidades de negócios, exigindo a revisão de sua forma de gestão, ao mesmo tempo em que sua trajetória propicia importantes liçōes a empreendedores que desejem iniciar negócios no mercado africano. Conclui que, a despeito da redução do apoio estatal e das mudanças no ambiente econômico interno e externo brasileiro, as oportunidades comerciais no Continente africano existem e não podem ser ignoradas pelos homens de negócios, que tendem a julgar a África como um todo em função dos aspectos negativos ressaltados pela im- 
prensa, da mesma forma que muitos empresários africanos desconhecem a qualidade dos nossos produtos e serviços.

Palavras-chave: Brasil, comércio internacional, África, relaçôes econômicas internacionais, Câmara de Comércio Afro-Brasileira.

\section{Abstract}

Economic relations between Brazil and Africa: The African-Brazilian Chamber of Commerce and the business interchange on the African market.

The text's objective is to answer three major questions: Under which motivations did the African-Brazilian commerce reach a noticeable growth between the 70's and the 90's? What are the perspectives presented to whoever Brazilian businessman that wants do some business in Africa? Nowadays, how are the businesses that began back then? Making use of bibliographical research and interviews with executives who have worked in Africa, besides specialists in exterior commerce, it was concluded that during this period the Brazilian government gave generous contributions to undertakings that focused on the African market, by stimulating the creation of companies and directing operations to that continent. With the end of this privilege policy, many companies bankrupted, while others remained with their activities. An example of the latter is the Chamber of Commerce, that points out the difficulties in creating new business opportunities, and this demands an administrative reevaluation. At the same time, the history of the Chamber teaches us important lessons to executives who want to do business on the African market. It concludes that, in spite of the reduction of the public support and the changes on the Brazilian intern and extern economic environment, the commercial opportunities on the African market really exist and cannot be ignored by the businessmen, who tend to misjudge Africa as a whole, given the negative aspects shown by the press. Besides, many American businessmen are unaware of the quality of our products and services.

Keywords: Brazil, international commerce, Africa, international economic relations, African-Brazilian Chamber of Commerce. 


\section{Résumé}

Les relations économiques Brésil - Afrique: la Chambre de Commerce Afro-Brésilienne comme l'intermédiaire des affaires sur le marché africain

Cet article a pour but de répondre à trois questions majeures: qu'est-ce qui justifie l'estraordinaire croissance du commerce entre le Brésil et l'Afrique dans les années 70 à 90 ? Quelles perspectrives s'ouvrent aux chefs d'entreprises brésiliens souhaitant entamer des affaires en Afrique? Quel est l'état actuel de ces iniciatives qui ont surgit pendant ces années-là ?

À travers une recherche bibliographique et des entretiens avec des cadres qui ont travaillé en Afrique, en plus de spécialistes en commerce extérieur, on a constaté que pendant ces années-là le gouvernement brésilien accordait de généreux avantages à tous les investissements dirigés vers le marché africain, en stimulant la création de beaucoup d'entreprises et en dirigeant de nombreuses opérations vers le continent africain. La fin de cette politique priviligée à causé la faillite de beaucoup d'entreprises tandis que d'autres sont encore en activité comme la Chambre de Commerce qui a des difficultés à trouver d'autres oportunités d'affaires ; cela lui impose de réviser ses modes de gestion en même temps que sa trajectoire donne d'importantes leçons aux envestisseurs qui veulent débuter des affaires sur le marché africain. On conclut que, en dépit de la réduction de l'aide de l'état et des changements dans le domaine économique, interne et externe, au Brésil, les chances commerciales sur le continent africain existent et ne doivent pas être ignorées par les hommes d'affaires; ceux-ci ont tendance à juger l'Afrique comme un tout, à partir des aspects négatifs mis en relief par la presse, mais en même temps par bien de chefs d'entreprises africains qui méconnaissent la qualité de nos produits et de nos services.

Mots-clés : Brésil, commerce international, Afrique, relations économiques internationales, Chambre de Commerce Afro-Brésilienne. 
A o voltarmos nossa atenção para o processo que envolve as relaendidas entre 1970 e 1990, observamos que se trata de um período de intensas transformaçōes no desenvolvimento desse intercâmbio, registrando destacados picos de elevação e declínio. Percebemos, também, que são muitas as razões, várias as circunstâncias, e extenso o número de atores cujos esforços individuais e coletivos possibilitaram a alavancagem desse intercâmbio, promovendo açóes concretas que permitiram, ao longo do período, o crescimento desse comércio. No âmbito empresarial, esse esforço possui grande significação, haja vista que, embora sem apoio governamental não exista exportação, é a presença e o empenho do segmento empresarial que representa a pedra fundamental e indispensável nesse processo. Não é à toa que, ao decidir, política e estrategicamente, buscar mercados, o governo convoca os empresários privados, os quais são obrigados, por vezes, a enfrentar negociaçóes morosas e complexas para que suas empresas possam atuar com eficácia.

Este artigo tem como propósito apresentar algumas reflexôes acerca da presença empresarial brasileira no mercado africano enfocando, particularmente, empreendimentos nacionais que se voltaram ao comércio Brasil-África entre as décadas de 70 e de 90 , um período de grandes transformações no desenvolvimento desse intercâmbio e, portanto, rico em acontecimentos e experiências. Trata-se, sobretudo, da tentativa do autor em esclarecer indagaçóes pessoais advindas do seu exercício profissional, enquanto servidor público de instituição voltada ao acompanhamento das atividades de comércio exterior. Nesse sentido, o presente texto objetiva responder a três dessas questôes. Primeiramente, sob que motivaçōes o comércio Brasil-África obteve um notável crescimento no período compreendido entre os anos 1970 e 1990? Em segundo lugar, quais as perspectivas que se apresentam para o empresário brasileiro que deseje efetuar negócios junto ao mercado africano? Em terceiro, qual o estado atual de iniciativas empresariais que 
emergiram nessa fase em que a história brasileira registra não apenas o mais alto crescimento desse intercâmbio, como também o seu mais forte declínio?

No aprofundamento dessas questôes empregou-se como recurso a pesquisa bibliográfica junto a universidades e instituições brasileiras voltadas para o comércio exterior. ${ }^{2}$ Além disso, foram de importante significado os depoimentos colhidos junto a executivos envolvidos em operações comerciais no mercado africano e a especialistas em comércio exterior, bem como informaçôes obtidas em fontes documentais de entidades de reconhecidas participaçôes no incremento do intercâmbio comercial entre o Brasil e a África: a Construtora Norberto Odebrecht e a Câmara de Comércio Afro-Brasileira, cuja trajetória singular será focalizada neste artigo.

No decorrer da pesquisa pode-se constatar que abordar temas que envolvem as relações comerciais entre o Brasil e a África é tarefa complexa, considerando-se que não são apenas os Estados que estão em causa, mas também os povos e os interesses dos agentes econômicos, determinando circunstâncias históricas e também momentos distintos. Este parece ser o entendimento de Renouvin (citado por Almeida, 1998:22) ao afirmar que "estudar as influências que se exercem sobre as relações internacionais deixando de lado o conjunto de circunstâncias de um momento ou de uma época seria falsear a perspectiva histórica". Dessa forma, perseguindo uma visão mais ampla das relações econômicas Brasil-África nas considerações, tornar-se-ão inevitáveis as alusões a fatores políticos e econômicos que influenciaram o comportamento empresarial brasileiro nas suas relações com o Continente africano.

Por outro lado, ainda que o propósito deste artigo seja aprofundar o conhecimento da experiência empresarial brasileira sem adentrar na análise das histórias individuais de seus atores, emergiu desta pesquisa a trajetória de vida de um dos executivos entrevistados, o qual nos surpreendeu tanto pela singularidade do caminho que percorreu na luta pela ascensão econômica e política dos descendentes de africanos no Brasil, quanto pelo exemplo de carreira empresarial de sucesso, calcada numa articulada ação político/comercial de promoção do intercâmbio Brasil-África. Por conseguinte, entendemos que um breve relato dessa história possa propiciar algum grau de compreensão sobre o processo de desenvolvimento das relações comerciais entre o Brasil e a África, e até mesmo oferecer a oportunidade de maior aproximação com essa fonte viva de pesquisa. 
Relações Econômicas Brasil-África: A Câmara de Comércio Afro-Brasileira...

\section{Adalberto Camargo, um empresário negro na política africana do Brasil}

A seguir, um pouco da história do ex-deputado federal Adalberto Camargo, cujas atividades em prol do intercâmbio Brasil-África têm sido alvo de manifestaçôes diversas da classe dirigente brasileira.

Negro, de origem humilde, Adalberto nasceu em Araraquara (SP), em 1928, enfrentando condições que aparentemente o predestinariam a uma vida de simples conquistas. Órfão de mãe aos cinco anos, foi morar com tios em uma fazenda no interior de São Paulo, onde vendia leite nas redondezas, atividade que mais tarde foi substituída pelas de vendedor de doces, na estação ferroviária, engraxate e ajudante de coveiro. Por conta disso, teve curta permanência nos bancos escolares. Freqüentou a escola até o quarto ano primário, concluído aos 16 anos, idade em que viu o seu pai pela primeira vez.

Nessa idade, sem profissão definida, mudou-se para a capital paulista, onde, sozinho, manteve-se trabalhando como marceneiro, atendente de armazém, vendedor de lingerie e auxiliar de tabeliāo, entre outras ocupaçōes, até transformar-se em proprietário da maior frota de carros alugados do país - a Auto-Drive, inspirada em experiência americana, que revolucionou o negócio de automóveis em São Paulo. A partir desse negócio, fundou e dirigiu outros empreendimentos, como a Mecanova S/A, a Afro-América Importação e Exportação e a Táxi Amarelinho, uma das pioneiras do ramo no Brasil, que consagrou a utilização do Volkswagen como carro de aluguel, rendendo-lhe grande prestígio junto aos altos círculos empresariais do país. Elegeu-se membro executivo do Conselho da Câmara de Comércio Estrangeiro, dirigiu a Federação do Comércio e também o Centro do Comércio do Estado de São Paulo.

Sua ascensão social é surpreendente, dados os grandes obstáculos que se interpõem aos negros que pretendem atingir patamares mais elevados na pirâmide social brasileira (Santana \& Camargo, 1999; Santana, 2000). Entrementes, foi no campo político que sua figura mais se notabilizou. Em 1966, aos 43 anos de idade, candidatou-se à Câmara Federal pelo Estado de São Paulo, vencendo as eleiçôes daquele ano com o suporte do "voto racial" da comunidade negra e o respaldo de suas entidades representativas (Aristocrata Clube, Casa da Cultura Afro-Brasileira, Grupo de Trabalho dos Profissionais Liberais e Universitários Negros, entre 
outras), que em seu primeiro mandato lhe renderam expressivos dezoito mil votos. Para isso contribuiu a retórica de seu discurso, voltado para a ascensão da comunidade negra, que buscava ampliar seus espaços de luta na sociedade. Nesse sentido, Adalberto declarava que:

[...] o negro se comporta como um mato sem raízes, só que mato sem raiz não dá frutos. Devido ao processo de colonização africana e da escravidão no Brasil, a comunidade brasileira descendente de africanos ficou distante de suas raízes e marginalizada no contexto internacional, em termos de construção da família negra no mundo. Por isso é muito importante que nós negros não estejamos apenas inseridos nos relacionamentos ditos culturais, mas também que estejamos inseridos nos relacionamentos comerciais e políticos que envolvem o Brasil e a África, pois são esses últimos que envolvem dinheiro e poder. Isso a nossa comunidade precisa para buscar uma maior afirmação e respeito da sociedade brasileira e mundial. Por isso é importante para nós trabalharmos no sentido de buscar interesses mútuos, tanto para a África como para o Brasil, pois nessa aproximação o Brasil terá oportunidade de resgatar de maneira pacífica a grande dívida que contraiu ao longo da história com o povo africano e, conseqüentemente, com os seus descendentes.

No pleito seguinte, Camargo conseguiu reeleger-se, com 43 mil votos, fato que repetiu em sucessivas eleições, mantendo-se no cenário político até 1978 . Com os noventa mil votos obtidos no pleito de 1974, tornou-se "a maior expressão eleitoral negra no Brasil” (Santos, 1993:8), servindo de estímulo para que outros candidatos negros se lançassem às urnas, muitos deles obtendo surpreendentes vitórias. Revela ele:

[...] quando comecei a freqüentar o MDB, percebi que todos os candidatos negros até então só foram candidatos pelo processo paternalista. Um negro se aproximava de uma liderança política qualquer, solicitava e conseguia uma legenda. Naturalmente, para demonstrar que não havia discriminação, porque eles não davam aquele suporte necessário para o indivíduo se eleger. Ele tinha compromisso e dívida de gratidão com seu padrinho político. Se eleito nada podia oferecer à comunidade porque tinha de prestar obediência ao elemento que o apadrinhou. Isso me levou à conclusão de que devia ingressar na vida pública sem ter padrinho. Eu não sou caudatário de nenhuma corrente partidária. Nunca fui da corrente classista, nem ideológica, nem estudantil, nem sindicalista. Eu era um homem comum, um homem do interior que veio para São Paulo tentar a vida. Eu fui eleito graças ao meu comportamento ao longo de toda a minha vida. Se eu tive capacidade de vender táxi, de ter uma empresa de locação de veículos, posso ser um político, porque o marketing está aberto. O negro anseia por alguma coisa e eu vou fazer a minha campanha só no meio negro. Eu quero a resposta para a pergunta: há realmente na comunidade negra a expectativa de se auto-afirmar no país? Eu não vou re- 
solver problema nenhum, vou sim iniciar um processo e os outros que continuem. A sociedade é mutável e, para o negro, a mutação é no sentido de melhorar a sua posição dentro da sociedade. Fui eleito dentro do meu projeto político. Elegi a Theodosina Ribeiro, o Paulo Rui e criei a Câmara de Comércio Afro-Brasileira para desenvolver um trabalho de aproximação com nossas origens. Criei, assim, o fenômeno histórico da maior importância nesse Estado, o negro nas três casas de representação popular, representação em todos os níveis. Só esse fato é suficiente para que a comunidade começasse a se conscientizar de que a sociedade é representativa, e pela primeira vez estávamos representados. Se representamos bem ou mal, não importa, porque o negro nunca teve tradição de vida pública, nem exercício da prática política e muito menos partidária. Negro nunca teve partido no Brasil. Nunca influiu em nenhum partido. Só começou a ter importância depois do meu advento. O problema do negro é a causa e não o partido, o negro nunca pertenceu a partido nenhum [...]. (Valente, 1983:72)

Ao final dos anos 60, funcionavam, em São Paulo, 45 câmaras de comércio, voltadas a estimular o intercâmbio com diferentes países e constituídas por empresários que tinham interesses nesses países. Conforme declara Adalberto Camargo, dada a inexistência de congênere voltada para o mercado africano, ele fundou, em 1968, a Câmara de Comércio Afro-Brasileira, quando, "para muita gente, na África só tinha Tarzan e Chita”. Visava ao incremento do comércio bilateral entre o Brasil e o Continente africano, intensificando a aproximação entre esses povos e fomentando o desenvolvimento de negócios, atividades culturais, científicas, tecnológicas e de cooperação.

\section{Câmaras de Comércio}

Por definição, as câmaras de comércio são associações sem fins lucrativos ${ }^{3}$ que congregam comerciantes e industriais que compartilham interesses em determinado ramo de atividades econômicas ou de negócios. Podem ter caráter regional ou ser de âmbito internacional, e destinam-se a apoiar as relações empresariais e econômicas entre os países, promovendo a criação dos meios institucionais mais adequados para o reforço e desenvolvimento dessas relações (Sandroni, 1999:74).

Prestam serviços de informações de mercados (recolhendo e divulgando dados sobre indicadores econômicos e sociais, legislação, tecido empresarial, prospecção de oportunidades etc.). Estudam e analisam problemas suscetíveis de dificultar o relacionamento empresarial, propondo às entidades oficiais competentes 
formas de sanar as dificuldades. Realizam encontros de empresários para esclarecimento e apresentação de programas e oportunidades, além de oferecer apoio logístico nos contatos com empresários e entidades estrangeiros (Daemon, 1986:218).

\section{Histórico e implantação da Câmara}

Em 1968, ano de criação da Câmara, a África ressurgia no contexto do governo militar como uma opção que atendia a amplos interesses do Brasil. O país buscava reduzir a sua dependência histórica em relação aos Estados Unidos e aumentar o seu poder de barganha internacional. Para tanto, iniciava uma política de ampliação de suas relações com o Terceiro Mundo. Instalam-se novos postos diplomáticos no Continente africano e inauguram-se linhas marítimas regulares para diversos portos da África. Conforme Skidmore, o ano de 1968 marcou a efetivação do trabalho, levado a cabo nos anos anteriores, de promoção da mentalidade exportadora: o governo concedeu incentivos à exportação, além de simplificar regulamentos e de promover a melhoria dos transportes internos (Skidmore, 1978:22).

De acordo com seus estatutos, a Câmara de Comércio Afro-Brasileira (CCAB), objetivava: a) promover a cooperação das entidades congêneres nos respectivos países; b) instituir e desenvolver esquemas informativos sobre mercadorias, tarifas, direitos e isenções aduaneiras, câmbio, navegação, tratados comerciais, legislação e jurisprudência relacionadas ao convênio bilateral; c) promover, organizar ou participar de congressos, seminários, simpósios, conferências, feiras, exposições e reuniões; d) formular proposições e elaborar programas visando ao aperfeiçoamento das trocas comerciais entre o Brasil e a África; e) organizar, coordenar e prestar assistência a missões comerciais brasileiras na África e vice-versa; elaborar e publicar análises setoriais e conjunturais das economias africanas; f) recepcionar delegações dos países do Continente africano em visita ao território brasileiro; promover a capacitação de recursos humanos para as atividades do comércio internacional, qualificando mão-de-obra especializada; g) editar revistas, jornais, boletins informativos, monografias, perfis promocionais e publicações similares, a fim de divulgar tudo que possa interessar à promoção, bem como à intensificação da atividade diplomática, comercial e cultural entre o Brasil e os países do Continente africano. 
O surgimento de uma entidade com o perfil da Câmara de Comércio Afro-Brasileira, nessa conjuntura, revestiu-se de singular relevância. Fazendo eco às propostas do governo de ampliar as relações com o Continente africano, a nova entidade ganhava as atenções e o importante apoio governamental em muitas das iniciativas por ela protagonizadas. Sua representatividade reforçava-se pelo fato de sua liderança ser exercida por um empresário negro bem-sucedido, que era, ao mesmo tempo, um político ligado ao governo militar, o que certamente possibilitou que a Câmara obtivesse simultaneamente expressiva aceitação no seio do empresariado nacional, notoriedade nos círculos governamentais e a simpatia das representações africanas.

Até o início de 1972, as atividades da Câmara limitaram-se ao estabelecimento de contatos iniciais e ao levantamento de da$\mathrm{dos}^{5}$ com vistas à composição de seu acervo documental e à formação de sua biblioteca. Em maio desse mesmo ano, em cooperação com a Secretaria de Cultura, Esportes e Turismo do Estado de São

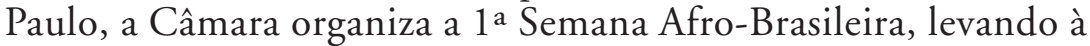
Assembléia Legislativa do Estado de São Paulo o ministro encarregado dos Negócios da Nigéria e vários embaixadores africanos.

Aproveitando a via de negociações aberta em novembro de 1972, com a visita oficial do ministro Gibson Barbosa a diversos países da África Ocidental, a Câmara iniciou um projeto similar: reuniu empresários brasileiros e os estimulou a comercializar diretamente com empresas africanas, eliminando as costumeiras triangulações efetuadas pelas tradings européias que reexportavam os produtos brasileiros para o Continente africano. Para tanto, uma equipe de técnicos da FAG - Traço, Arquitetura Promocional S.A., empresa brasileira contratada pela $\mathrm{CCAB}$ - viajou por diversos países africanos em trabalhos de prospecção. Estabeleceu contatos preliminares e realizou estudos de viabilidade que se concretizaram na $1^{\text {a }}$ Missão Comercial Brasileira a Países da África, cujo propósito era promover a colocação de produtos e serviços brasileiros no mercado africano por meio da mostra direta e de contatos pessoais com importadores, comerciantes, industriais, financistas e homens de governo.

\section{A primeira missão comercial brasileira a países da África}

A iniciativa teve lançamento oficial em maio de 1973, num jantar para quinhentos convidados no Hotel Hilton-SP, com a pre- 
sença do ministro das Relações Exteriores do Brasil, do governador do Estado de São Paulo, de embaixadores africanos e de diversas lideranças governamentais e empresariais, o que demonstra o prestígio da entidade e a representatividade do evento. Em discurso pronunciado naquela oportunidade, o ministro Gibson Barbosa enfatizava:

Esta missão pioneira [...] realmente corresponde à intenção com que o Governo enviou uma missão oficial à África, pois é isso que queremos. Nós podemos apenas abrir as portas e indicar caminhos e dar a moldura legal, jurídica, através de acordos internacionais para que os senhores, simultaneamente, façam a verdadeira obra de aproximação e de cooperação com todos esses países. Essa iniciativa, portanto, só pode ser objeto dos aplausos mais sinceros por parte do Governo. ${ }^{6}$

A viagem realizou-se no período de 25 de setembro a 29 de outubro de 1973 , com a participação de 37 representantes de indústrias brasileiras, ${ }^{7}$ além de cinco funcionários governamentais, ${ }^{8}$ fortalecendo a representatividade da delegação que percorreu Senegal, Costa do Marfim, Gana, Togo, República Popular do Benim (antigo Daomé), Nigéria, Camaróes, Zaire e Líbia. Acompanhava a Missão uma mostra itinerante com mais de duzentos produtos de origem brasileira que eram apresentados em exposições montadas em cada uma das capitais visitadas.

Assim, compradores e governos africanos tomavam conhecimento do estágio de desenvolvimento brasileiro e, aos participantes da delegação brasileiras, eram proporcionados meios de aferirem a realidade econômica dos países independentes da África. Os empresários brasileiros pouco conheciam da realidade africana, o que pode ter criado dificuldades para a realização de muitos negócios. Além disso, a influência política do presidente da Câmara junto ao empresariado e ao governo da época representava um grande trunfo para a viabilização de empreendimentos promovidos pela entidade. Tudo isso fica evidenciado neste depoimento de Adalberto Camargo:

Nenhum de nós tinha ido para a África antes. Ninguém sabia nada, nem tinha informações em lugar nenhum. Aí eu fiz um questionário para poder elaborar o projeto e informar à comunidade brasileira [...] quanto a reservas de hotéis, translado, custo de viagem, eu fiz um acerto com o Banco Real através da Turismo Real. Eu expliquei para o Diretor do Banco qual era o objetivo e a proposta e eles financiaram os empresários. $\mathrm{O}$ empréstimo foi feito sem a mínima obrigação. Só com a minha garantia. $\mathrm{Na}$ base do meu pedido, de meu nome. Em função disso mais tarde, eu propiciaria a ele a oportunidade de começar os contatos para abrir uma 
agência do Banco Real na Costa do Marfim. [...] eu exigi do governo que a delegação tivesse representante do governo e então eles me indicaram cinco representantes. O Delfim Neto numa audiência que teve comigo me prometeu dois, representando o Ministério da Fazenda. O Gibson me pediu para incluir a Libéria no roteiro e veio fazer o discurso de lançamento da Missão [...].

Competia à Câmara representar oficialmente a exposição perante os poderes públicos nacionais e estrangeiros; convidar governos e empresários para participar da mostra ou visitá-la; manter serviços de divulgação, segurança, orientação e assistência aos expositores; promover a aproximação entre os membros da delegação e as entidades interessadas.

A realização de uma missão comercial na África pela Câmara de Comércio Afro-Brasileira foi um empreendimento marcado pelo pioneirismo, dada a complexidade que envolve tal operação, o variado leque de atores, recursos e cenários envolvidos. 'Sem contar que o reduzidíssimo número de executivos negros em posição de comando nas empresas brasileiras implicaria a formação de uma comitiva cuja ausência de afro-brasileiros poderia causar constrangimentos, com repercussões negativas no decurso das negociações.

Eu fiquei preocupado de levar uma missão comercial para a África que não tinha empresário negro. Eu mandei fazer uma pesquisa para levantar quais eram os empresários negros preparados e não achei. Eu fui obrigado a travestir onze negros como empresários para levar nessa missão. Eu tive que fazer uma certa ginástica, pois eu fiquei pensando: bem, vou fazer uma missão comercial do Brasil para a África, levando quarenta e cinco empresários brasileiros e vou levar quarenta e cinco brancos? Vão ver isso como missão de capitão do mato na África. Sabe o que eu fiz? Consegui que onze empresários permitissem que eu escolhesse onze negros para ir lá representar suas empresas e fazer o jogo. Esses negros foram ganhando. E eu fui fazendo o meu cinema, meu filme. Fui tomar conta do filme. Eu fiz isso, eu consegui convencer as empresas, dentre elas uma empresa israelense.

Outra situação delicada enfrentada pela delegação relacionava-se à comparação que com certeza se estabeleceria entre as empresas brasileiras e aquelas tradicionalmente estabelecidas no Continente africano. As intensas ligações mantidas com a Europa e a longa tradição de contato com empresas e produtos europeus haviam desenvolvido vínculos de confiança e preferência entre os consumidores africanos. Além disso, uma cotidiana troca de informações permitia a atualização constante desses consumidores em 
relação aos produtos e serviços europeus, tornando-se plausível que as ex-metrópoles, por meio de empresas instaladas na região, buscassem exercer o controle sobre as novas iniciativas que se apresentassem, conforme se pode depreender do seguinte depoimento:

O Banco Nacional de Paris na época era o único que atendia ao esquema de pagamento do comércio entre a África e o resto do mundo. Aí o seu presidente, Joseph Ferré, mandou me chamar por conta da Missão. Disse que queria colaborar e fez uma pequena cartilha recomendando a cada membro da delegação que abrisse uma conta no BNP, quer dizer: ele previu que dessa missão iriam surgir muitos negócios e queria todos nós, exportadores, como clientes do BNP, porque, como ex-colonizadores, eles dominavam o esquema financeiro da África. Todos as transaçôes internacionais dependiam do BNP e eles queriam manter esse controle sobre a delegação brasileira.

Por fim, a complexidade de uma operação desse quilate acentuava-se na medida em que a África, rica em sua diversidade cultural e em potencialidades de comércio, constituía um mercado praticamente desconhecido para a quase totalidade dos empresários brasileiros. Nesse aspecto, Pereira apontava na época que:

O modo como a África é vista ou a imagem que dela nos é dada para consumo constitui um exemplo marcante desse colonialismo cultural. Apresentada como uma totalidade amorfa, onde a diversidade só é mostrada pela atomização tribal, a África é analisada ainda hoje entre nós em termos discriminatórios. Nessa visão europocêntrica da História impera uma concepção dualista, falsa, maniqueísta. Segundo ela, as metrópoles possuiriam cultura de valor; a África, costumes exóticos. O que é filosofia e religião na Europa toma os nomes de crendice ou superstição na África. As lutas sociais nas metrópoles, analisadas pela sociologia e pela ciência política, na África são reduzidas a lutas tribais - chave explicativa para todos os conflitos - e entregues ao estudo de uma antropologia de matriz colonial. No estudo da formação de nossa nacionalidade, a participação dos africanos e de seus descendentes é escamoteada e relegada a uma "contribuição ao folclore, à culinária e ao misticismo". A África permanece para a maioria dos brasileiros reduzida a uma imagem simplificada por quatro t: tribo, tambor, terreiro e ...Tarzan (Pereira, 1978:16).

Para atenuar as dificuldades, o corpo diplomático brasileiro forneceu o apoio logístico: recepção, chancela oficial da operação, facilitação dos trâmites burocráticos e acesso a personalidades locais. Cabe ressaltar que em 1973, sob o Governo Médici, desenvolvia-se um amplo projeto comercial voltado para o Continente africano em que diplomacia e agências de governo articulavam-se no sentido de fornecer um tratamento especial às iniciativas orientadas nessa direção. Dessa maneira: 
[...] a delegação foi acolhida com grande simpatia pelos parceiros africanos, sendo importante a participação do governo brasileiro que, através do Itamaraty e das embaixadas brasileiras nos países visitados, facilitou os contatos com os governos e empresários africanos. Então, quando a delegação chegava em cada país, já estava tudo organizado e programado. Tudo esquematizado, convites distribuídos e contatos agendados com as personalidades do governo e empresários africanos...

Sob o ponto de vista do intercâmbio comercial, a Missão rendeu dividendos positivos, especialmente às empresas que dela participaram, fazendo aumentar o interesse de compradores africanos por produtos brasileiros, como também o de importadores brasileiros por produtos africanos. Isso pode ser inferido parcialmente das estatísticas oficiais brasileiras no ano imediatamente seguinte: de 1973 para 1974 , as exportaçôes brasileiras cresceram $129,1 \%$, passando de US\$190.001.000 para US\$ 435.323.000, enquanto as importações originadas do Continente africano tiveram o expressivo crescimento de $300,2 \%$, avançando de US\$ 169.903.000 para US\$ 679.998.000.

\section{Quadro 1}

\section{Exportações e Importações Brasileiras} para a África - 1972-1974 (em US\$1.000)

\begin{tabular}{|c|c|c|}
\hline Ano & Exportaçōes & Importações \\
\hline 1972 & 90.390 & 152.967 \\
\hline 1973 & 190.001 & 169.903 \\
\hline 1974 & 435.323 & 679.998 \\
\hline
\end{tabular}

Fonte: Banco do Brasil, Cacex.

\section{O apogeu da Câmara}

A partir de 1973, os contatos brasileiros e africanos se intensificaram. A Câmara experimentou um efetivo crescimento do seu quadro de filiados, que em 1976 somavam 102 empresas, indicando o aumento na solicitação de serviços. Com isso, aumentava a especialização de seu quadro operacional, cuja estrutura apresentava novo dimensionamento, com quatro diretorias e vários departamentos, além da presidência e da vice-presidência. Da mesma forma, amplia-se o número de correspondentes associados no Brasil e no exterior, demonstrando um esforço agressivo em busca de novas oportunidades no Continente africano. Cresce também o nú- 
mero de participações da Câmara em feiras, missóes comerciais e outros eventos no Brasil e no exterior. ${ }^{10}$

O trânsito político do então deputado federal Adalberto Camargo dava à entidade maior visibilidade, favorecendo os contatos nos meios diplomáticos e empresariais. Nas palavras do embaixador Asdrúbal Pinto de Ulysseia, chefe do Departamento de África do Ministério das Relações Exteriores:

O deputado Adalberto Camargo é um amigo de longo tempo e conhecido do Itamaraty. Nós todos, lá, temos por ele um apreço muito grande. Não só ele tem dado muito de si para esse trabalho de congraçamento com a África, mas ele tem sido também um assessor que conosco troca pontos de vista. E nós, naturalmente, que não nos consideramos donos da verdade, nos sentimos extremamente felizes em poder trocar idéias com homens como Adalberto [...]. (AfroChamber, 1983:12)

Nesse contexto, o quadro associativo da Câmara chegou a contar com cerca de trezentos filiados - empresas de médio e grande porte que se utilizavam do assessoramento da entidade na busca de informações sobre a África. ${ }^{11}$ A esse respeito, os convênios mantidos com órgãos governamentais relacionados ao comércio exterior eram de fundamental importância, bem como o acervo documental da entidade, mantido por meio da assinatura ou intercâmbio de periódicos e revistas africanos, de cujo noticiário se extraia material editorial para o Relatório Informativo distribuído quinzenalmente aos seus associados. Editada pela Câmara, a revista AfroChamber chegou a atingir uma tiragem de vinte mil exemplares, ${ }^{12}$ apresentando um painel atualizado com informaçōes sobre empresas, oportunidades de negócios, feiras e eventos, no Brasil e na África. Dirigida a empresários, era também distribuída entre representações governamentais brasileiras e de outros países.

Por sua vez, a proximidade do seu presidente junto aos altos círculos de poder atraía a presença, a adesão e o respaldo do Estado aos eventos promovidos pela Câmara, a exemplo do $1^{\circ}$ Simpósio Brasil-África de Comércio, realizado em novembro de 1980 com o objetivo de identificar possibilidades e interesses que pudessem estimular novos esforços de cooperação mútua. Os Ministérios das Relações Exteriores, da Fazenda, da Agricultura, da Indústria e do Comércio, juntamente com a Secretaria de Planejamento da Presidência da República, a Secretaria da Indústria, Comércio, Ciência e Tecnologia do Estado de São Paulo e o Banco do Brasil, foram os patrocinadores do simpósio, que teve como palestrantes o gover- 
nador do Estado de São Paulo, ministros e embaixadores brasileiros, entre outras autoridades.

Ao final do ano seguinte, a participação africana no total das exportaçōes brasileiras cresce a níveis surpreendentes, alcançando $8,4 \%$. O comércio Brasil-África atinge sua "época de ouro". De fato, podemos observar que em 1984 as exportaçôes para aquele Continente chegam a US\$1,976 bilhão, representando 7,3\% das exportações totais brasileiras, e em 1985 alcançam o pico de US\$ 2,021 bilhões, ou seja, 7,9\% das exportações totais.

Tabela 1

Exportações Brasileiras - 1979-1986 (em US\$ 1.000)

\begin{tabular}{c|c|c|c|c|c}
\hline Ano & Total & $\begin{array}{c}\text { Variação } \\
(\%)\end{array}$ & África & $\begin{array}{c}\text { Participação no } \\
\text { Total (\%) }\end{array}$ & Variação (\%) \\
\hline 1979 & 15.244 .377 & 20,4 & 692.882 & 4,5 & 4,3 \\
1980 & 20.132 .401 & 32,1 & 1.313 .199 & 6,5 & 89,5 \\
1981 & 23.295 .356 & 15,7 & 1.963 .267 & 8,4 & 49,5 \\
1982 & 20.180 .966 & $-13,4$ & 1.390 .229 & 6,9 & $-29,2$ \\
1983 & 21.903 .182 & 8,5 & 1.237 .555 & 5,7 & $-10,8$ \\
1984 & 27.006 .553 & 23,3 & 1.976 .458 & 7,3 & 59,4 \\
1985 & 25.639 .028 & $-5,0$ & 2.021 .688 & 7,9 & 2,3 \\
1986 & 22.348 .713 & $-12,8$ & 945.123 & 4,2 & $-53,4$ \\
\hline
\end{tabular}

Fonte: Ministério do Desenvolvimento Indústria e Comércio Exterior, Secex.

\section{O declínio da Câmara}

Nesse contexto, a figura parlamentar de Adalberto Camargo enfrenta o declínio político. Não conseguindo a reeleição no pleito de 1984 , ele se afasta da vida política, o que parece afetar diretamente o dinamismo que a entidade havia alcançado na década anterior. A perda do espaço político certamente retirava-lhe certo poder de manobra e de influência junto ao empresariado e ao governo no sentido de mobilizá-los e atraí-los para as iniciativas de interesse da entidade. As atividades da Câmara se reduzem e os relatórios de atividades enviados aos filiados deixam de ser produzidos.

Por sua vez, o novo panorama que ao fim da primeira metade dos anos 80 se descortina no Brasil, na África e no sistema internacional impõe dificuldades em ambos os lados do Atlântico. Diante disso, decai o interesse brasileiro pelo Continente africano. As taxas de juros do dólar, que eram de 3\% a 4\% em 1973, se elevam 
para 22\% e 23\% em meados dos anos 80 . Na África, os golpes de Estado e a instabilidade política marcavam a vida do Continente. Os efeitos da dívida externa, a insuficiência de recursos para o desenvolvimento e os rigorosos programas de ajustamento estrutural coordenados pelo FMI e pelo Banco Mundial fragilizaram as economias africanas, reduzindo a capacidade destas em ampliar o comércio exterior para os mercados do Sul. ${ }^{1}$

No Brasil, a dívida externa passa de U\$ 25 bilhões em 1975 para US\$ 105 bilhões em 1985, e a sua renegociação resulta em perda de liquidez da economia. Com isso, reduz-se também a capacidade do país em dar sustentação a sua política comercial em direção ao mercado africano (d'Adesky, 1998:2). Em 1986, o volume das exportações para a África sofre uma redução significativa, de US\$1.076.575.000, com a participação no total das exportações brasileiras diminuindo de 7,9 para 4,2\%. Essa queda vai tornar-se mais acentuada nos anos 90, quando as exportações para a África experimentaram, de 1992 a 1996, um quadro de estagnação, com resultados em torno de US\$ 1,5 bilhão, muito aquém do pico alcançado em 1985. Com tudo isso, em 1996 o mercado africano representava apenas 3,2\% das exportações brasileiras.

Tabela 2

Exportações Brasileiras - 1985-1996 (em US\$1.000)

\begin{tabular}{c|c|c|c|c|c}
\hline Ano & Total & $\begin{array}{c}\text { Variação } \\
(\%)\end{array}$ & África & $\begin{array}{c}\text { Part. no } \\
\text { Total (\%) }\end{array}$ & Variação (\%) \\
\hline 1985 & 25.639 .028 & 5,0 & 2.021 .688 & 7,9 & 2,3 \\
1986 & 22.348 .713 & 12,8 & 941.694 & 4,2 & $-53,4$ \\
1987 & 26.223 .956 & 7,3 & 1.018 .038 & 3,9 & 8,1 \\
1988 & 33.789 .567 & 8,8 & 983.259 & 2,9 & $-3,4$ \\
1989 & 34.382 .619 &, 7 & 1.000 .510 & 2,9 & 1,8 \\
1990 & 31.413 .759 & 8,6 & 1.033 .783 & 3,3 & 3,3 \\
1991 & 31.620 .461 &, 6 & 1.132 .553 & 3,6 & 9,6 \\
1992 & 35.792 .985 & 3,2 & 1.098 .301 & 3,1 & $-3,0$ \\
1993 & 38.554 .712 &, 7 & 1.108 .025 & 2,9 & 0,9 \\
1994 & 43.545 .162 & 2,9 & 1.346 .746 & 3,1 & 21,5 \\
1995 & 46.506 .282 &, 8 & 1.584 .953 & 3,4 & 17,7 \\
1996 & 47.746 .728 &, 6 & 1.521 .987 & 3,2 & $-4,0$ \\
\hline
\end{tabular}

Fonte: Ministério do Desenvolvimento Indústria e Comércio Exterior, Secex. 
Como se vê, a crise da "década perdida" arrefeceu o comércio com o Continente africano, fazendo reduzirem-se ainda mais as atividades da Câmara. $\mathrm{Na}$ atualidade, esta já não exibe o vigor nem o dinamismo antigos, tampouco a imagem arrojada que a consagrou nos anos 70 e possibilitou a realização de diversos negócios, incrementando o comércio entre o Brasil e a África. A criação da Câmara foi, sem dúvida, uma iniciativa pioneira e de grande significado para o crescimento desse intercâmbio. Atualmente, contudo, ela demonstra pouca expressão na conquista de novos negócios e reduzida capacidade de atrair novas filiações ou mesmo de atender solicitaçôes de serviços que costumava prestar. A esse respeito, considere-se que as receitas auferidas pelas câmaras de comércio, embora estas sejam caracterizadas como entidades sem fins lucrativos, provêm de quotas pagas por seus filiados e das atividades de prestação de serviços que elas realizam. Qual seria então a estratégia a implementar para dinamizar a Câmara e aumentar o número de filiados e de atividades de prestação de serviços?

Seguramente, as oportunidades de negócios no Continente africano existem; o que falta é mais agressividade da ação empresarial para aproveitá-las. Como exemplos, podemos tomar países que exibem elevados níveis de exportaçóes para o Brasil, sem que haja uma correspondente contrapartida de exportaçôes brasileiras. Aí estariam incluídos a Argélia, o Congo e a Costa do Marfim, de onde o Brasil importa uma elevada quantidade de produtos, mas para os quais não exporta em nível proporcional. Trata-se de importantes mercados consumidores que, por falta de uma agressiva política de colocação da oferta exportável brasileira, tornam-se cativos compradores de produtos europeus, conforme demonstramos abaixo:

No ano 2000, enquanto as exportações brasileiras para a Argélia foram de US $\$ 41.405 .084$, as importações provenientes daquele país alcançaram a cifra de US\$1.507.250.981. A Argélia é uma das mais ricas nações da África. Importa de países como Itália, Estados Unidos, França e Espanha cerca de 40\% dos alimentos consumidos por sua população, além de veículos e bens de capital. Trata-se de itens que o Brasil produz e em relação aos quais o mercado exportador brasileiro exige a busca de fórmulas inovadoras que viabilizem operações.

Exportando para o Brasil um montante de US\$ 3.823.934 em contrapartida a uma importação de US\$74.008.278, o Congo é uma economia fundamentada principalmente na agricultura de subsistência. Possui poucas indústrias manufatureiras e a quase to- 
talidade dos produtos industrializados que consome provém da França e da Holanda. Suas principais indústrias processam produtos agrícolas, tecidos, cimento, calçados e presunto. Desde 1998, está sendo implementado um plano de reconstrução nacional para a reabilitação de serviços de transporte, telecomunicações, saúde e administração pública.

De acordo com o Anuário Abril-2001, a Costa do Marfim é uma das nações mais prósperas do Oeste africano em razão de sua produção agrícola e mineral. Nos últimos anos o governo tem estimulado o crescimento de setores da indústria alimentícia (como os de palmito e peixes) e têxtil, mas o volume das importações é elevado, com predominância de produtos oriundos da França, Estados Unidos, Holanda, Gana, Itália e Burkina Faso. As exportações brasileiras para a Costa do Marfim no ano 2000 foram de US\$ 21.629.840, tendo o cacau como principal produto, enquanto as importações, pelo Brasil, de produtos daquele país atingiram US\$ 63.288.588.

As novas oportunidades de negócios não se encerraram nos exemplos desses grandes exportadores de petróleo, pois, segundo Pimentel (2000:17), outros mercados também revelam uma oferta potencial de novas oportunidades comerciais para o Brasil, tendo inclusive motivado recentes incursōes de empresas brasileiras, assentadas sobre um projeto âncora ou uma idéia-força. Nesse caso se incluem: a República dos Camarões, país em que a Andrade Gutierrez vem desenvolvendo empreendimentos promissores; o Gabão, onde se efetuam negociações para a instalação de uma mini-siderúrgica pela Iscom; Gana, que se tem distinguido no interior da $\mathrm{CEDEAO}^{15}$ pelo equilíbrio da atuação diplomática e pelo estímulo à integração econômica; a Guiné Equatorial, onde a Braspetro desenvolve negociaçôes; o Mali, alvo de atençôes do Banco Mundial e para o qual a Companhia de Desenvolvimento do Vale do São Francisco - Codevasf elaborou importante projeto; a Namíbia, que oferece condições excepcionais para a entrada de produtos brasileiros em território africano e com a qual a Marinha do Brasil mantém exemplar cooperação.

\section{Pontos de estrangulamento na Câmara}

Como se vê, tais mercados mereceriam maior investimento de esforços da Câmara no sentido de identificar negócios que despontam nesses países e que são do interesse de empresas brasileiras. 
No entanto, a participação da Câmara em feiras internacionais, um instrumento potencializador de oportunidades, diminuiu e a sua atuação na dinamização do comércio com esses países se vê limitada em função da restrição de seus recursos técnicos, humanos e administrativos para a promoção de negócios. Por exemplo, a partir de 1994 a Câmara parou de editar a revista AfroChamber, importante veículo de promoção de negócios, fechando um eficiente canal de comunicação com empresas e governos, potenciais demandadores de seus serviços. Segundo o presidente da entidade, reduziu-se "bastante" a demanda de prestação de serviços da Câmara, bem como o número de seus filiados, que "caiu para cerca de 50 ". ${ }^{16} \mathrm{O}$ quadro interno de funcionários também se restringiu, e hoje "gira em torno de 10 pessoas".

A esse respeito, entendemos que, para executar as atividades previstas nos seus estatutos, a entidade conta com um reduzido quadro de recursos humanos, o que certamente limita a sua dinamização, considerando-se que, diferentemente de suas congêneres, ${ }^{17}$ a atuação da CCAB pretende abarcar um vasto leque de países que nem sempre dispõem de sistemas de informação eficientes. Se compararmos a atuação da Câmara de Comércio Afro-Brasileira com outras de atuação bilateral, deveremos constatar um nível mais baixo de produtividade na realização de seus serviços, com reflexos inclusive na qualidade da informação. A nosso ver, as câmaras de comércio bilateral favorecem o aprofundamento e a qualidade de processamento das informações, tornando possível melhorar o nível de especialização de seus funcionários. Acreditamos que no caso da Câmara de Comércio Afro-Brasileira a segmentação dos serviços em departamentos regionais (África do Norte, África do Leste, África Austral etc.) poderia constituir-se em alternativa a ser estudada para aumentar a produtividade e mesmo a especialização, dados os poucos recursos humanos de que ela dispóe.

A entidade é administrada a partir de uma estrutura hierárquica simples, liderada desde a sua criação pelo mesmo presidente, ao qual se subordinam um vice-presidente, um diretor e uma secretária, além dos demais funcionários, que executam os serviços demandados à entidade. Percebe-se ali uma estrutura de comunicação do tipo "cubo e raios", em que o presidente representa o pólo difusor e receptor de todas as informações. Sob esse aspecto, a estrutura da entidade se assemelha às de organizações do tipo "empresa familiar", em que as estratégias empresariais e sua sistematização são repassadas da "cabeça do proprietário-controlador" para 
seus colaboradores (Bernoeft, 1989). Como sugere o depoimento seguinte, há uma forte concentração de poder e de controle das decisões sobre um único indivíduo, o que pode ocasionar dificuldades adicionais para implementar processos de mudança na organização, além de criar obstáculos ao curso sucessório na entidade: "Qualquer informação tem que ser comigo. Ninguém aqui está autorizado a dar informação sem minha ordem" (Hartmann, 1997:48; Scheffer, 1993).

Nessas condições, entendemos que os sistemas de administração e comunicação carecem de práticas modernas de gestão e de descentralização de poderes com vistas a permitir a maior difusão das informações, especialmente por se tratar de organização voltada para o comércio exterior, o qual se desenvolve num ambiente internacional de contínuas transformações e incorpora fatores altamente sensíveis a modificações. A esse respeito, Sato (2000:138) salienta que:

[...] mudanças tecnológicas, por exemplo, em um curto espaço de tempo, podem alterar fluxos comerciais e financeiros tornando um grande negócio de hoje uma atividade econômica inviável amanhã. Disponibilidade de mão-de-obra e de recursos naturais deixaram de ser, a médio prazo, garantias para as nações. Mesmo estruturas industriais maduras, para não serem ultrapassadas, precisam modernizar-se continuamente tanto do ponto de vista tecnológico quanto administrativo [...]. Países e regiôes não se transformam na mesma direção e quando, porventura, o sentido das mudanças pode ser considerado semelhante, a velocidade com que esse processo ocorre difere substancialmente de lugar para outro $[\ldots]$.

Constatamos na Câmara um reduzido grau de aproveitamento das modernas tecnologias de informação. A Internet, por exemplo, é uma importante ferramenta empresarial, por permitir a troca de informações a um custo baixo e de maneira simples e rápida. Nas operaçôes de comércio exterior, trata-se de instrumento imprescindível no que se refere a pesquisas, atualização de dados e envio de correspondência. Embora a CCAB disponha de um endereço eletrônico, grande parte de sua correspondência ainda é enviada, desnecessariamente, por via postal, o que implica custos mais elevados e menor agilidade da informação.

Além disso, a inexistência de um website da Câmara limita o alcance de sua visibilidade no mercado. Com uma homepage, poder-se-iam trocar informações de parte a parte com muito mais eficiência, sanar dúvidas, gerar curiosidade e interesse em brasileiros e africanos, contribuindo para reduzir o ainda grande desconheci- 
mento desses mercados. Conforme se depreende da fala de Aderaldo O. Anjos, vice-presidente da CCAB, há necessidade de maior informatização da entidade:

[...] o banco de dados e os nossos arquivos já estão meio defasados, inclusive estamos levantando dados sobre o que você faria para viajar, comer, tentando atualizar. Antes a gente tinha tudo isso em pasta, atualmente vai ter que se jogar tudo isso no computador e [...] se aparecer uma pesquisa de um determinado país, temos que recorrer ao próprio país, porque nosso banco de dados está desatualizado. Para mim, o futuro é informatizar toda a Câmara para atender aos associados de uma maneira rápida e com dados atuais $[\ldots] .^{18}$

Por outro lado, a rede mundial de computadores parece provocar uma certa redução da demanda dos serviços das câmaras de comércio, restringindo-lhes as fontes de receita. A esse respeito, poder-se-ia tomar como exemplo a experiência da Mendes Júnior Trading e Engenharia S.A., sediada em Belo Horizonte, que usa a Internet para identificar negócios de interesse da empresa: "O serviço é utilizado com o objetivo de propiciar o desenvolvimento das ações iniciais que possam conduzir à materialização de negócios”, afirma o engenheiro Victório Duque Semionato, diretor de negócios estratégicos da empresa, acrescentando ainda que, levantadas as informaçōes comerciais dos novos negócios, juntam-se "as informações recebidas das embaixadas brasileiras, que nos permitem ter conhecimento das oportunidades existentes em vários países e analisar as tendências dos negócios no mercado internacional. Assim, no caso de interesse em determinados negócios, solicitam-se informações adicionais para análise” (Web, 2001).

A partir de 1998, o Ministério das Relaçōes Exteriores criou a Brazil Trade Net (www.braziltradenet.gov.br), serviço de informações gratuito voltado para a atividade exportadora e para a atração de investimentos estrangeiros. Nesse site, que recentemente atingiu a faixa de 500 mil acessos, estão cadastradas cerca de 49 mil empresas estrangeiras e 13 mil nacionais, apresentando oportunidades de negócios e estudos de mercados na área de serviços e de produtos não-tradicionais (Itamaraty, 2001).

Torna-se evidente que, para permanecer atuando no mercado e aumentar a eficiência de seus resultados, a Câmara de Comércio Afro-Brasileira precisa ampliar o seu quadro de filiados e, mais que isso, implementar ações no sentido de atrair negócios que promovam o crescimento da demanda de serviços da entidade. Percebe-se que iniciativas potencialmente catalisadoras de negócios, 
como seminários, missões comerciais e participação em feiras internacionais, deixaram de acontecer ou perderam a freqüência dos anos iniciais da entidade. Isso, além de reduzir o peso e a força da entidade na atração de novos filiados, implicou a perda de diversas oportunidades de prestação de serviços.

\section{A Câmara de Comércio Brasil-República Sul-Africana: um exemplo a seguir?}

Uma nova Câmara de Comércio emerge no cenário das relações Brasil-África. Trata-se da Câmara de Comércio Brasil-República Sul-Africana, criada em 1991, cuja atuação oferece importante contribuição ao crescimento do comércio brasileiro com a África do Sul, país que, a partir de 1994, se tornou o maior importador de produtos brasileiros no Continente africano. Uma visita técnica à Câmara de Comércio Brasil-República Sul-Africana conduziu-nos à percepção de que ali se desenvolve um exemplo modelar da nova experiência empresarial brasileira no Continente africano. Entendemos que, por se tratar de nações cujos sistemas de informação nem sempre são eficazes, o relacionamento bilateral parece produzir maiores resultados do ponto de vista do estreitamento de relações e da cooperação entre órgãos representativos dos dois países. Ademais, esse relacionamento se nos afigura a conduzir a um maior aprofundamento e especialização das informações, constituindo-se num instrumento importante na elaboração de estratégias de atração de negócios dessa Câmara.

Entre outras constatações, observamos que a Câmara de Comércio Brasil-República Sul-Africana faz uso de modernos recursos de administração, o que lhe garante maior rapidez e qualidade nas informações, as quais provêm de um banco de dados atualizado por especialistas em comércio exterior. Verificamos também que seu trabalho se desenvolve em estreita colaboração com a Embaixada da África do Sul, em cuja homepage estão inseridas informações sobre a entidade, conferindo-lhe maior visibilidade e representatividade no mercado empresarial. Constatamos ainda que existe um extenso cronograma de visitas, palestras e missóes comerciais, evidenciando a existência de uma coordenada política de atração de novos negócios e filiados. ${ }^{19}$

Nesse sentido, observa-se que, ao longo desses anos, a entidade vem se tornando uma referência para empresários interessados em exportar para a África do Sul. Demonstrando o empenho 
dessa Câmara em gerar oportunidades que se convertam em negócios, Fernando Tomé, manager da Câmara de Comércio Brasil-República Sul-Africana, declara que:

[...] a matéria-prima do nosso trabalho é a informação comercial. Todavia, em virtude da representação relativamente pequena que a África do Sul tem no Brasil, a Câmara acaba extrapolando a área comercial e presta informaçōes das mais diversas voltadas a turistas, estudantes e a quem estiver interessado em conhecer um pouco mais do país, pois entendemos que dessa forma estamos incentivando indiretamente o comércio. $\mathrm{O}$ papel político também é considerado, uma vez que acordos diplomáticos, comerciais e técnicos aproximam ainda mais os dois países. Por isso, cultivamos um relacionamento estreito com o Ministério das Relaçôes Exteriores, assim como estamos sempre presentes nas recepções de autoridades sul-africanas aqui no Brasil. O estreito contato com associaçôes de classe (Federações de Indústria, Sebraes, associações de fabricantes etc.) tem se mostrado eficiente, fazendo-nos atingir um maior número de candidatos à exportação/importação para/da Africa do Sul. Mantemos um convênio com universidades sul-africanas onde duas vezes por ano recebemos turmas de executivos e futuros executivos, estudantes de MBA, para quem ministramos palestras e os acompanhamos em visitas para conhecimento da realidade brasileira. [...] A divulgação de feiras sul-africanas para empresários brasileiros vem sendo feitas de várias maneiras e alcançando muito sucesso, pois sabemos que é uma das maneiras mais simples e eficazes de introdução do produto made in Brazilno mercado sul-africano. Por exemplo, nessa última feira em 2001, o estande do Brasil, que nós coordenamos, ganhou o primeiro lugar entre todos os estandes da feira. As feiras sul-africanas a cada dia se especializam e crescem em tamanho e importância, na mesma medida que vem crescendo o interesse do empresariado brasileiro na África do Sul. ${ }^{20}$

A tais afirmações, deve-se acrescentar que a estrutura de recursos humanos da Câmara de Comércio Brasil-República Sul-Africana compõe-se de doze profissionais de formação especializada ou de nível superior que se utilizam de modernas ferramentas de gestão e abordagem de negócios. Isso sugere haver ali a efetiva visão de negócios que parece ter se enfraquecido ao longo do tempo na Câmara de Comércio Afro-Brasileira, o que teria contribuído para reduzir a eficiência dos seus resultados.

Diante dessas consideraçôes, entendemos que o modelo de atuação da Câmara de Comércio Afro-Brasileira necessita de séria revisão no sentido de dotá-la de maior dinamismo para atender a um mercado cada vez mais exigente e que requer das empresas o desenvolvimento de sua capacidade estratégica. Para tanto, listamos aqui alternativas que, em nossa visão, poderiam contribuir para a reversão da tendência declinante dessa atuação: 
a) criação de departamentos regionais (África do Norte, África Oriental, África Austral etc.) chefiados por especialistas;

b) na ausência de recursos para contratação de especialistas, seria essencial limitar a atuação da Câmara, escolhendo regiōes ou países estratégicos, como por exemplo produtores de petróleo, países de língua portuguesa etc;

c) produção de relatórios anuais e de perfis socioeconômicos de cada país;

d) arregimentação de novos sócios com campanhas de telemarketing e de assinatura da revista AfroChamber,

e) dinamização dos contatos mediante a organização de visitas de empresários africanos ao Brasil;

f) realização de pesquisas de mercado para produtos específicos;

g) criação de banco de dados com atualização permanente;

h) produção de página na web.

Entendemos que a entidade tem muito a contribuir, especialmente no horizonte desta nova ordem mundial em que novas formas de integração política e econômica se estabelecem buscando maior cooperação nos vários setores, a exemplo da Comunidade dos Países de Língua Portuguesa, ${ }^{21}$ da Zona de Paz e Cooperação do Atlântico Sul ${ }^{22}$ e da Comunidade de Desenvolvimento da África Austral (Southern African Development Community $\mathrm{SADC}),{ }^{23}$ destinadas a promover a aproximação entre seus membros e formar parcerias para fortalecer ações bilaterais e negociações junto aos países industrializados.

Além disso, acreditamos que a dinamização do comércio Brasil-África continua sendo um imperativo estratégico na razão direta dos nossos progressivos déficits na balança comercial com aquele continente. As potencialidades desse intercâmbio existem, pois, em que pese à debilidade da situação econômica de muitos países, há várias economias africanas que desde 1994 vêm obtendo taxas anuais de desenvolvimento econômico superiores a 5\%, com alguns desempenhos individuais destacados acima de 10\%, o que justifica maior interesse e agressividade das empresas brasileiras (Pimentel, 2000:6).

Por fim, entendemos que a Câmara de Comércio Afro-Brasileira teve destacado papel na dinamização das relações entre o Brasil e o Continente africano, e que a vasta experiência acumulada ao longo dos anos constitui importante legado para o 
desenvolvimento de negócios. Ademais, não se podem desprezar as oportunidades abertas, o vasto número de africanos formados por escolas brasileiras que ampliaram o conhecimento mútuo das realidades de lá e de cá, tampouco o vasto legado de capital humano composto por engenheiros, técnicos e diplomatas brasileiros que viveram na África no período áureo do comércio bilateral. Um capital que vem sendo reforçado por associações de empresas que demonstram claramente um elevado interesse em fechar negócios com os países africanos, como o COLYMAR (Círculo Olympio Marques - Centro de Empresários Afro-Brasileiros), o CEM (Centro de Estudos e Aperfeiçoamento de Empreendedores) e o CEABRA (Coletivo de Empresários Afro-Brasileiros).

\section{Perspectivas empresariais em horizonte futuro: últimas consideraçõos}

Ao voltar a atenção para as relações comerciais Brasil-África, observamos tratar-se de um intercâmbio de há muito estabelecido, mas que, no cômputo geral, ganhou relevância no período compreendido entre os anos 70 e 90. Marcado por elevados picos de crescimento e declínio, o comércio Brasil-África nessa época tem sua condução fortemente estimulada pelos sucessivos governos que incentivavam a conquista de novos mercados e a exportação de artigos de maior valor agregado, fazendo com que nesse período se observe uma marcante presença do empresariado brasileiro no mercado africano.

Como pudemos observar, essa movimentação empresarial em direção ao Continente africano, iniciada nos anos 70, foi conduzida no âmbito da estratégia governamental de substituição de importações, tratando-se, mais especificamente, de um desdobramento dessa estratégia, ou seja: à medida que o crescimento da indústria nacional via substituição de importações gerava estoques invendáveis, o governo se via forçado a incentivar não apenas as exportações de artigos de maior valor agregado (manufaturados), mas também a conquista de novos mercados.

Estimulada pelas emergentes relações Sul-Sul, ${ }^{24}$ que estimulavam o intercâmbio de países do Terceiro Mundo, a busca por novos mercados vai encontrar na África uma nova opção para o destino das exportações brasileiras. Essa opção era favorecida não apenas pela destacada fonte de suprimento de petróleo e outras matérias-primas cruciais ao desenvolvimento do modelo econômico 
implantado no Brasil em que se constituíam os países africanos, mas igualmente pela manifesta disposição destes em encontrar parceiros no contexto Sul-Sul.

Assim, no início dos anos 70, multinacionais estrangeiras com filiais no Brasil e empresas de capital nacional são fortemente estimuladas pelo governo brasileiro a direcionarem parte de suas exportações para o Continente africano. Pudemos perceber que a adesão das empresas ao esforço exportador do governo foi conseguida, em grande parte, à custa de generosos incentivos fiscais, creditícios e cambiais, entre outros, que eram colocados à disposição de empresas voltadas para a exportação - setor de atividades bastante privilegiado entre os anos 70 e 80 , em função de interesses do governo, aos quais se associava a "vontade de potência", de elevar o País a um patamar superior no concerto das nações.

Nesse particular, como se pôde inferir, a reaproximação do Brasil com a África nos anos 70 não foi um fato natural, decorrente dos anos de contatos com o Continente africano, mas um ato político decorrente de um projeto de inserção internacional para o Brasil que buscava na África atender interesses materiais e políticos de afirmação de autonomia no mundo. Assim, sob o impulso do Itamaraty e de outros órgãos de governo, o Estado investiu maciçamente na conquista de novos mercados na África. Estreitaram-se laços políticos, criaram-se Embaixadas, promoveram-se eventos diversos, estimulando-se também o desenvolvimento de novos meios e formas de facilitar as exportações para o continente africano. Apostava-se nas potencialidades da região, ao tempo em que se buscava persuadir setores influentes da sociedade para se engajarem no esforço exportador do governo. Isso pode ser percebido pelo grande número de eventos patrocinados pelo governo brasileiro nesse período, além das facilidades e incentivos (fiscais, creditícios, cambiais, entre outros) concedidos aos empreendimentos que exportavam para a África.

As atividades de fomento à exportação fizeram com que diversas empresas surgissem nesse período ou voltassem seus empreendimentos para o mercado africano, contribuindo, dessa forma, para que a participação africana no total do comércio exterior brasileiro, ao início dos anos 80 , se elevasse a índices jamais alcançados. Essa situação chama a atenção na medida em que o auge dessas relaçôes foi alcançado num período, do ponto de vista econômico, bastante conturbado para o Brasil - a década de 80 foi considerada uma "década perdida", de grave desequilíbrio nas contas externas e de inflação alta, quase incontrolável. Mas, a despeito 
desse elevado crescimento do comércio Brasil-África na década de 80, no decênio seguinte o intercâmbio comercial, pelo contrário, regrediu. A crise econômica que abalou o mundo ao final dos anos 80 refletiu-se negativamente nos anos seguintes, atingindo profundamente as economias africanas ao retirar-lhes a capacidade de ampliar suas relações com o Hemisfério Sul. O Brasil, por sua vez, ao efetuar a renegociação da dívida externa, perdeu parte de sua liquidez e conseqüentemente grande parcela de sua capacidade de sustentar uma política em direção à Âfrica, concedendo subsídios, incentivos e demais facilidades às exportações.

A política de estabilização da economia e a reforma do Estado brasileiro exerceram consideráveis influências no arrefecimento desse comércio, na proporção em que levaram o País a eleger uma política cuja abertura comercial privilegiava a relação com os tradicionais parceiros industrializados (Estados Unidos e União Européia) e priorizava uma política regional em direção ao Mercosul. Isso torna-se evidente nas palavras do ministro das Relaçôes Exteriores do Brasil, em 1995, ao afirmar que uma prioridade da política externa brasileira "é o processo de consolidação do Mercosul, o seu eventual engrandecimento com a incorporação de novos parceiros, o seu relacionamento com outras comunidades econômicas, com destaque para União Européia e Nafta e sua incidência na estabilização e na retomada do crescimento" (Lampreia, 1975:115). Com a reforma do Estado, percebe-se que, do ponto de vista do comércio externo, o País se distancia da África. Conformando-se com os princípios da globalização e do livre mercado, que estimulavam a desregulamentação e a privatização, o papel do Estado vai progressivamente diminuindo.

Como se pôde observar, nas duas primeiras décadas do período estudado o empresariado brasileiro foi alvo de ponderáveis medidas de fomento à exportação para o mercado africano, razão do sucesso de muitos empreendimentos, alguns dos quais ainda hoje prosseguem atuando em operaçôes voltadas para o comércio africano, como a Câmara de Comércio Afro-Brasileira que se reveste de exemplo significativo da ação empresarial brasileira na África.

A CCAB obteve o importante apoio do governo brasileiro nas suas operações direcionadas ao mercado africano. Isso incluiu o estabelecimento de várias condições especiais e de mecanismos facilitadores como o countertrade, a viabilização da implantação de linhas aéreas e marítimas, a concessão de financiamentos e linhas de créditos especiais monitoradas por bancos estatais, a designa- 
ção de funcionários governamentais brasileiros para assessorar operaçôes comerciais além de participação e envolvimento direto em eventos promovidos pela Câmara.

A Câmara de Comércio tinha na sua liderança um parlamentar de considerável influência no círculo governamental, e isso certamente contribuía para chamar a atenção da classe política para as iniciativas dessa entidade, conferindo-lhe prestígio e promovendo a maior adesão de interessados no comércio Brasil-África. Além disso, a estreita aproximação com os altos círculos de um governo disposto a colaborar com iniciativas voltadas para a África permitia facilitar trâmites burocráticos e sensibilizava as autoridades para a redução de obstáculos e a obtenção do apoio de órgãos oficiais. Desse modo, as atividades da Câmara de Comércio no exterior tinham o decisivo suporte do Itamaraty e de outros organismos do governo brasileiro, cujos serviços e até funcionários eram disponibilizados nos eventos promovidos pela entidade, respaldando ou mesmo viabilizando suas operaçôes. Exemplo dessa atitude pode ser observado na inclusão de funcionários governamentais acompanhando a missão comercial a países africanos organizada pela Câmara em 1973.

Não se pode desprezar a disposição do empresariado brasileiro em aproveitar as oportunidades de negócios surgidas no âmbito do comércio Brasil-África, como também o seu empenho no enfrentamento de dificuldades nada convencionais. Aí estariam incluídos o conflito angolano, a preferência africana por produtos e serviços europeus, a insuficiência de transportes diretos e o desconhecimento mútuo das respectivas realidades.

Como se afirmou anteriormente, a partir dos anos 90 houve uma redução progressiva da intervenção do Estado brasileiro na economia. Ao mesmo tempo, os números do comércio Brasil-África diminuíram significativamente e, da mesma forma, percebe-se que as atividades da Câmara se reduziram. O vínculo entre a redução da intervenção estatal no comércio Brasil-África e o arrefecimento das atividades da Câmara torna-se visível na medida em que, nesse período, se reduzem os eventos promovidos pela entidade. Certamente por isso, deixa-se de publicar o relatório de atividades anteriormente enviado aos filiados, extingue-se a revista AfroChamber, diminui o número de filiados e de solicitação de serviços.

Tais elementos parecem sinalizar para uma redução da capacidade da Câmara de atrair novos negócios na África, bem como de ampliar o número de interessados brasileiros no comércio africa- 
no. Isso torna-se preocupante em se tratando de uma entidade privada que busca a aproximação de comerciantes em busca de oportunidades de negócios que, em nosso entendimento, não têm sido devidamente exploradas, embora sejam de efetivo interesse para empresas brasileiras e africanas, especialmente as pequenas e médias.

Em face de uma insuficiente conformação aos novos ditames do mundo dos negócios, a Câmara parece ter se engessado, o que sugere a perda de uma parcela de sua força negocial. A atuação em um mercado cada vez mais exigente e competitivo requer das empresas o desenvolvimento de sua capacidade estratégica, o que significa ampliar o horizonte de visão dos negócios, criando e desenvolvendo uma postura pró-ativa e antecipatória. No caso de uma entidade de negócios atuando num mundo cada vez mais globalizado, esta necessita não apenas ser hiperativa, mas também manter uma constante reciclagem.

Como Santos (1992), entendemos que o futuro de qualquer empresa é um campo aberto de possibilidades, mas que é possível influir na construção desse futuro, desenvolvendo a capacidade de perceber tanto as ameaças e oportunidades no ambiente externo como as forças e fraquezas no ambiente interno, potencializando dessa forma os pontos fortes e minimizando os pontos fracos de uma gestão empresarial. Acreditamos que a Câmara esteja a necessitar da implantação de um modelo de gestão estratégica que incentive o compartilhamento e a construção de um projeto coletivo para a entidade. Como ponto de partida, um bom exemplo seria instituir reuniões de coordenação, um espaço formal da entidade em que, mediante encontros sistemáticos entre os seus integrantes, se constrói a estratégia de ação e se faz o acompanhamento das ações da organização.

Esse espaço, se bem estruturado, colaboraria para a formação e o desenvolvimento de capacidades estratégicas dos seus componentes, pois pessoas com visões e percepções diferentes discutiriam seus pontos de vista sobre um mesmo tema, chegando a acordos e tendo como resultado um trabalho de fato coletivo. Isso permitiria a antecipação de problemas e sua solução, bem como a melhor administração de conflitos e o fortalecimento da ação da entidade no mercado.

Por sua vez, os novos cenários do mundo dos negócios exigem a utilização intensiva de modernas ferramentas de gestão. Estas parecem incorporar-se de forma bastante lenta ao dia-a-dia da Câmara de Comércio Afro-Brasileira, que não possui uma pági- 
na na web e parece utilizar pouco a Internet, além de possuir um banco de dados que carece de atualização. Tais constatações estariam a indicar a necessidade de sérias reformulações na forma de atuação da Câmara a fim de que esta possa continuar a exercer o significativo papel desempenhado nos "anos de ouro" do comércio Brasil-África. Seu nome, sua história e seu passado constituem um legado que não se pode desprezar, tendo em vista a ampla experiência e o grande conhecimento acumulados ao longo dos anos no desenvolvimento de negócios no Continente africano.

Entre outras medidas recomendadas ao longo deste texto, entendemos de grande potencial a intensificação da atuação da Câmara mediante a organização de seminários para empresários, visitas a associaçóes de classe, viagens e encontros internacionais com grupos de empreendedores africanos, com a finalidade de apresentar as potencialidades do comércio brasileiro, proporcionando condições para a ampliação do diálogo entre homens de negócios dos dois lados do Atlântico.

A despeito das mudanças no ambiente econômico brasileiro e da redução progressiva do apoio estatal nos anos 90, constatou-se na pesquisa que a Construtora Norberto Odebrecht experimentou uma continuada ampliação de suas atividades no continente africano. Ela se instalou em outros países da região e, por meio do "efeito vitrine", ampliou o seu raio de ação para outros continentes. Por tais constatações, a experiência dessa empresa estaria a demonstrar que as relações comerciais com o Continente africano são viáveis, suscitando diversas indagações: será que hoje em dia uma grande empresa brasileira que desejasse iniciar negócios na África poderia conseguir êxito seguindo o modelo adotado pela Odebrecht? E no caso de uma pequena ou média empresa?

Diante do que apresentamos ao longo deste estudo, percebe-se que as condições no Brasil se modificaram e, portanto, empresas que desejarem iniciar operaçôes no mercado africano já não podem copiar aquele modelo de atuação. Uma empresa brasileira que, na atualidade, resolva dirigir suas exportaçóes para o mercado africano terá de partir de novas bases, já que não poderá contar com a vasta gama de incentivos creditícios e financeiros concedidos no passado pelo governo brasileiro. Extinguiram-se as linhas diretas semanais que ligavam o Brasil a diversas cidades africanas, como Lagos (Nigéria), Abidjan (Costa do Marfim), Luanda (Angola) e Maputo (Moçambique). À exceção dos dois vôos diretos semanais para a África do Sul, os contatos aéreos com o Conti- 
nente africano se efetuam de forma triangular, com passagem pela Europa.

Por sua vez, diferentemente dos "anos de ouro" do comércio com a África, a empresa não vai mais encontrar uma economia que, dada a elevada prioridade atribuída à exportação, colocava os recursos da burocracia estatal à disposição das empresas interessadas nessa atividade. Assim, com o capital financeiro escasso no Brasil e nos países africanos, em lugar dos empréstimos a juros subsidiados, antes concedidos por bancos oficiais, as empresas são hoje obrigadas a contar com seus próprios recursos ou recorrer a empréstimos a taxas de juros de mercado oferecidos pelos bancos privados. Em contrapartida, no horizonte do século XXI, o Brasil, da mesma forma que os países africanos, ampliou o conhecimento sobre esse intercâmbio. Cresceu no País o número de centros de estudos sobre a África, contabilizando um reforço em termos de capital intelectual e de recursos humanos proveniente do maior número de africanos e brasileiros que atuaram nesse comércio.

A rede mundial de computadores facilitou o conhecimento de oportunidades de negócios. Análises de possibilidades de países e mercados africanos podem ser inferidas de sites de organismos internacionais, como os da ONU, ONUDI, OUA e FAO, entre outros. A BrazilTradeNet (www.braziltradenet.gov.br), site do Departamento de Promoção Comercial do Ministério das Relações Exteriores, oferece gratuitamente um amplo conjunto de oportunidades de negócios, informações e pesquisas sobre produtos e mercados, endereços úteis, notícias, links e outros dados de interesse para exportadores brasileiros. Nesse site, a empresa pode incluir uma oferta de exportação para ser consultada por congêneres de fora do Brasil, além de obter informaçôes sobre as condições gerais de acesso de seu produto a um país ou bloco econômico. Assim, uma pequena ou média empresa que esteja procurando negócios no mercado africano deve incorporar a Internet a sua rotina de trabalho. A isso se deve acrescentar a busca de oportunidades junto a câmaras de comércio, ${ }^{25}$ consulados e embaixadas de países africanos no Brasil.

Já no caso de uma grande empresa, cujo aporte financeiro é mais elevado, a especialização e o aprimoramento dos recursos humanos e tecnológicos revestem-se de importância capital. Dispondo de departamento de exportação próprio, a permanente atualização de seus quadros, em sintonia com as tendências mundiais, a torna mais capacitada para atuar nesses mercados. A assinatura de periódicos especializados em África, o envio de representantes 
para conhecer pessoalmente as potencialidades dos países africanos, o permanente contato com empresas estrangeiras e nacionais que detêm o conhecimento dos mercados locais constituirão importantes ferramentas a serem consideradas. Em certas circunstâncias, seria recomendável buscar a associação com outras empresas em torno de projetos de joint-venture. Convém ainda ressaltar que, a exemplo das grandes empresas européias, norte-americanas e asiáticas, a intenção de permanecer no continente africano parece fator de grande importância para o sucesso nesse tipo de empreendimento, haja vista que essa presença contínua tende a propiciar um maior domínio dos mecanismos comerciais, assim como maior rapidez na adaptação aos mercados.

A atuação da Odebrecht no Continente africano revela a experiência bem-sucedida de uma empresa do setor de exportação de serviços - um setor importante que dispõe da propriedade de produzir impactos positivos sobre a economia do país de origem, com destaque para a geração de outras exportações de bens de capital, serviços e produtos. Ao mesmo tempo, a condição empresarial brasileira nos dias atuais é, reconhecidamente, de grande potencial instalado, com altos níveis competitivos e tecnológicos, especialmente nessa área de exportação de serviços. Tanto assim que, no caso dos projetos de consultoria, engenharia e construção, o Brasil detém tecnologia de ponta, sendo esse o único setor da economia nacional em que as empresas são consideradas verdadeiramente multinacionais, com competência mundialmente reconhecida. A engenharia nacional, por exemplo, está presente em mercados altamente competitivos do Primeiro Mundo, como Estados Unidos, Inglaterra e Alemanha.

Assim, será que as empresas que exportam projetos de consultoria, engenharia e construção, atividades em que o país detém tecnologia de ponta, são aquelas com maiores possibilidades de êxito no mercado africano? Que outros empreendimentos foram bem-sucedidos? Quais deles fracassaram? Quais as razões desses sucessos/fracassos? Como se pode ver, são muitas as questões cujas respostas poderiam nortear outras pesquisas cujos resultados certamente contribuiriam para aprofundar o conhecimento da experiência empresarial brasileira dos anos 70 aos 90 .

Caberia acrescentar que as considerações aqui apresentadas advêm do entendimento de que as conjunturas brasileira, africana e internacional estão continuamente a criar novas oportunidades e desafios que não podem ser ignorados pelos homens de negócios deste País, a despeito das dificuldades que sempre existirão nas re- 
lações com qualquer país ou região. No caso africano, tais dificuldades estariam vinculadas, sobretudo, à recorrente instabilidade política e econômica de boa parte desses países, determinando um "custo África" que cria obstáculos à instalação ou operação de empresas brasileiras naquele continente.

Buscando averiguar quais os mercados africanos que se apresentariam como promissores para o desenvolvimento de negócios brasileiros nos horizontes do ano 2002, o pesquisador consultou Especialistas em África e deles recolheu impressões que nos levaram à conclusão de que, excluídas algumas grandes empresas que procuraram consolidar sua presença no Continente, o setor privado brasileiro não está familiarizado com as diferenças entre os diversos países africanos. Por isso, tende a julgar a África como um todo em função dos aspectos negativos ressaltados pela imprensa, da mesma forma que, em sentido inverso, muitos empresários africanos desconhecem a qualidade de nossos produtos e serviços.

Percebeu-se ainda que as relações comerciais entre o Brasil e o Continente africano hoje se concentram, em grande medida, nos países petrolíferos, como Líbia, Nigéria, Gabão, Argélia, Angola e Congo Brazzaville. Além desses países, destaca-se a África do Sul, que desponta como parceiro de elevado valor estratégico em função de sua posição geográfica e do seu nível de desenvolvimento industrial, que é elevado em comparação com os de outros países africanos. Brasil e África do Sul são os pólos mais desenvolvidos do capitalismo em seus respectivos continentes, o que se expressa não só na grandeza de seus PIBs, mas também nos respectivos graus de sofisticação industrial. Acrescente-se a isso a condição privilegiada de observador de que a África do Sul desfruta no Mercosul, além do fato de poder ser considerada um trampolim para a penetração em todo o subcontinente da África Austral, região de apreciável valor econômico derivado da produção e reserva de vários minerais estratégicos, situada entre os oceanos Índico e Atlântico e fronteiriça ao cone sul da América Latina.

Também o mercado dos países africanos da CPLP foi apontado como um mercado potencial para a venda de mercadorias e serviços, tais como a construção civil, a agropecuária etc. A língua portuguesa comum e o interesse político do governo brasileiro em desenvolver maior cooperação representariam um grande atrativo para impulsionar um intercâmbio comercial de grandes potencialidades. Trata-se de um mercado com cerca de quarenta milhões de pessoas cujas afinidades culturais e familiaridade com o Brasil são estimuladas por condições semelhantes em termos de terreno e de 
clima. Além disso, as empresas brasileiras possuem vantagens comparativas para participar no desenvolvimento africano, pois o patamar tecnológico dessas empresas permite a atuação em setores de média complexidade, dotados de capacidade indutora, como a formação profissional, a construção civil, a agricultura e outros.

Tratam-se de perspectivas múltiplas e atraentes, que ainda assim nos apontam para novas questôes: sob que outras formas de atuação empresas brasileiras se estabeleceram no continente africano no período estudado? Que situaçōes poderiam ser apontadas como potencializadoras do sucesso (ou do fracasso) dessas iniciativas? Em tempos de globalização, com o peso hegemônico das relações econômicas Norte-Sul, seria possível ou desejável reativar o intercâmbio Sul-Sul? Será que, no contexto da globalização, o governo brasileiro deveria voltar a priorizar as relações com a África? São questões, como muitas outras, cujas respostas seriam de muita utilidade para pesquisadores interessados no tema das relaçôes comerciais Brasil-África, além de ampliar o conhecimento sobre o comportamento do empresariado nacional, provendo o campo da administração, (fortemente contaminado por influências estrangeiras) com informações retiradas do contexto brasileiro - rica fonte de ensinamentos para as novas gerações de empreendedores.

\section{NOTAS:}

1. Este artigo resultou de dissertação de mestrado. Agradeço ao professor Dr. Jacques d' Adesky pelos comentários e orientação.

2. O desenvolvimento da pesquisa ressaltou a quase inexistência de estudos sobre negócios brasileiros a partir da realidade nacional, justificando as ponderações de Aquino (1986) quanto ao estudo da administração em nosso país ser fortemente contaminado por influências estrangeiras fazendo com que um vasto número de experiências empresariais e de gestão sejam pouco exploradas, o que poderia fornecer substanciais contribuições ao campo da administração, provendo instituições responsáveis pela formação de novas geraçôes de empreendedores de informações retiradas do próprio contexto nacional.

3. Embora caracterizadas como sem fins lucrativos, as receitas dessas entidades provêm de quotas pagas por seus filiados e das atividades de prestação de serviços que realizam

4. A imagem do presidente da Câmara refletia um empreendedor negro de sucesso.

5. Esses dados eram obtidos em sua maioria junto a fontes européias e nos países interessados, pelo que se imagina serem muitas vezes incompletos e desatualizados. Essa situação evidencia o insuficiente conhecimento da África não apenas da parte do empresariado, mas da sociedade brasileira como um todo, já que as informações divulgadas pela imprensa eram poucas, produto de agência internacionais. Quase não ha- 
via livros, ainda que traduzidos, sobre a África, e existiam apenas dois centros de estudos africanos: o CEAO na Bahia e o CEAA no Rio de Janeiro.

6. Discurso proferido na solenidade de lançamento da Missão.

7. A Missão prestou serviços de representação de produtos de 62 firmas brasileiras de diversos setores de atividade, como a Plantel Import. e Export., a Evasian Indústria de Calçados, a Afro-América Import e Export Ltda., a Persianas Colúmbia S.A., a Eucatex, a Suzano Pffeifer Ind. de Papéis, a BSA Consultoria Financeira e Export., a Ind. de Sacos Acácio Camargo etc. Fonte: documento cedido pela CCAB.

8. As entidades governamentais que enviaram representantes foram: Ministérios das Relaçôes Exteriores, da Fazenda, da Indústria e do Comércio, Cacex, Companhia de Promoção de Exportação de Manufaturados do Estado de São Paulo - Copeme e Lloyd Brasileiro. Fonte: documento cedido pela CCAB.

9. A África compunha-se de nações ainda em processo de descolonização e outras recém-independentes - em estágio de formação de quadros políticos.

10. A CCAB participou de feiras internacionais na Nigéria (1973), Senegal (1974), Zaire (1975), Gana (1976) e Moçambique (1979), além de missão comercial a Zâmbia, liderando um grupo de empresários brasileiros. Essas informações constam de relatório dirigido aos filiados com um balanço das atividades executadas pela Câmara até o final de 1982. A partir desse ano, o relatório deixou de ser emitido, possivelmente para evitar a divulgação do decrescente desempenho da Câmara nos anos seguintes.

11. Os serviços disponibilizados pela Câmara aos seus filiados compreendiam o fornecimento de informaçôes referentes ao mercado africano no que tange à exportação e importação de produtos, incluindo tarifas aduaneiras, direitos de importação, promoções de produtos e serviços brasileiros, assessoramento e trâmites diplomáticos no exterior, oportunidades comerciais, emissão e autenticação de certificado legais e documentos para credenciamento em concorrências internacionais, pedidos de cotação etc.

12. A AfroChamber tinha periodicidade bimestral, com versões em português (dez mil exemplares), inglês (cinco mil) e francês (cinco mil).

13. Entre 1980 e 1984, os investimentos brutos nos países africanos, vinculados a aportes das agências multilaterais, diminuíram $22 \%$, passando de $18,6 \%$ para $10,8 \%$ do PIB (Pimentel, 2000:10).

14. Os dados referentes aos países mencionados foram recolhidos do site do Ministério das Relações Exteriores do Brasil. Disponível em www.mre.gov.br, e do Anuário Abril 2001.

15. CEDEAO ou ECOWAS - Comunidade Econômica dos Estados da África Ocidental, órgão regional de cooperação econômica.

16. A divulgação dos filiados é uma ação que as câmaras costumam realizar quando solicitadas. Redunda em propaganda para entidade. Do conhecimento de quantos e quais são seus filiados, pode-se inferir o peso da organização e a sua representatividade. Não foi permitido ao pesquisador o acesso a essas informações o que poderia sugerir que ou não existem filiados na quantidade informada ou a entidade não tem a representatividade que tenta demonstrar.

17. Câmara de Comércio Brasil-Angola, Câmara de Comércio Brasil-Nigéria, Câmara de Comércio Brasil-República Sul Africana. 


\section{Ivo de Santana}

18. Trechos da entrevista concedida pelo Sr Aderaldo O. Anjos, vice-presidente da CCAB.

19. Essa Câmara, tem como filiados empresas, de grande porte e notoriedade, como General Motors, Mercedes Benz, Petrobrás, Ypiranga, entre outras.

20. Trecho de entrevista de Fernando Tomé concedida ao pesquisador na sede da CCBRAS.

21. A CPLP foi criada em Lisboa, em 1996, com a finalidade de reunir os sete países lusófonos - Brasil, Angola, Cabo Verde, Guiné-Bissau, Moçambique, Portugal e São Tomé e Príncipe - no propósito de buscar: a concertação político-diplomática entre seus membros; a cooperação econômica, social, cultural, jurídica e técnico-científica; e a promoção e difusão da língua portuguesa.

22. A ZPCAS foi estabelecida em 1986 pelos países da costa ocidental da África e pelos países latino-americanos banhados pelo Atlântico Sul. Esses 24 países buscam uma forma de integração e colaboração regional.

23. A SADC criada em 1992 com o objetivo de incentivar as relações comerciais entre os quatorze países-membros da África meridional, visando criar um mercado comum e estabelecer a paz e segurança na região.

24. As relações Sul-Sul correspondem a um movimento implementado no seio dos países do Terceiro Mundo incentivando as trocas recíprocas como forma de reforçar os laços econômicos e reduzir a sujeição global aos países desenvolvidos.

25. As câmaras voltadas para o comércio com a África são: Câmara de Comércio Afro-Brasileira, Câmara de Comércio Brasil-Angola, Câmara de Comércio Brasil-República Sul-Africana e Câmara de Comércio Brasil-Nigéria.

\section{Referências bibliográficas:}

AFROCHAMBER (1983). Discurso proferido na solenidade de fundação da Câmara de Comércio Brasil-Nigéria em 22 de setembro, p. 12.

ALMEIDA, P. R. de (1998). Relaçôes internacionais e política externa do Brasil: do descobrimento à globalização. Porto Alegre, UFRGS.

BERNOEFT, R. (1989). A empresa familiar: sucessão profissionalizada ou sobrevivência comprometida. São Paulo, Nobel.

D’ADESKY, J. (1998). “O paradoxo das relações comerciais Brasil-África”. Network, vol. $7, n^{\circ} 3$, set.-dez.

DAEMON, D. (1986). Negociaçôes em mercados internacionais: análise e casos de operaçôes comerciais na Europa Oriental, África, Oriente Médio. Rio de Janeiro, FGV/Nova Fronteira.

HARTMANN, J. (1997). "Empresa familiar: negócios em extinção? Empreendedor oportunidade de negócios”. Mulher de Negócios, vol. 2, n 25, nov.

"ITAMARATY intensifica ajuda a empresários na busca de novos mercados". Relnet Resenha Econômica, disponível em <http//www.relnet.com.br>, acesso em 20 de novembro de 2001.

LAMPRÉIA, L. F. (1975). “Apresentação na Comissão de Relações Exteriores da Câmara dos Deputados". Resenha de Politica Exterior do Brasil, no 76. 
PEREIRA, J. M. N. (1978). "Colonialismo, racismo, descolonização". Estudos Afro-Asiáticos, no 2, pp. 16-29.

PIMENTEL J. V. de S. (2000). "Relações entre o Brasil e a África subsaárica”. Revista Brasileira de Política Internacional, no 43, pp. 5-23.

SANDRONI, P. (1999). Novíssimo dicionário de economia. São Paulo, Best Seller.

SANTANA, I. de. (2000). "Executivos negros em organizaçōes bancárias de Salvador: dramas e tramas do processo de ascensão social”. Afro-Ásia, no 23, pp. 199-237. \& CAMARGO, C. L. de (1999). "Infância e adolescência de executivos negros: um estudo retrospectivo". Revista Brasileira de Crescimento e Desenvolvimento Humano, vol. 9, no 2, pp. 74-89.

SANTOS, G. G. dos. (1993). Partidos políticos: etnia negra em São Paulo. Dissertação de Mestrado em História, São Paulo, PUC-SP.

SANTOS, L. A. A. dos (1992). Planejamento e gestão estratégica nas empresas. São Paulo, Atlas.

SATO, E. (2000). "A agenda internacional depois da Guerra Fria: novos temas e percepçôes”. Revista Brasileira de Política Internacional, no 43, pp. 138-169.

SCHEFFER, A. B. B. (1993). "Sucessão em empresas familiares: dificuldades e ações preventivas". In: ENANPAD, 17.

SKIDMORE, T. (1978). "O papel do Brasil em face do sistema internacional: implicações em relação à política norte-americana”. In: R. Roett, O Brasil na década de 70. Rio de Janeiro, Zahar, pp. 22-37.

VALENTE, A. L. E. F. (1983). Política e relações raciais: os negros e as eleições paulistas de 1982. São Paulo, FFLCH/USP.

"WEB é atalho para comércio exterior". Gazeta Mercantil Latino-Americana, São Paulo, 5.11. 2001. 